\title{
TANGGAP DARURAT MEDIS (CODE BLUE) STUDI KASUS PADA RUMAH SAKIT UMUM DAERAH ABDUL WAHAB SJAHRANIE DI SAMARINDA
}

\author{
Widya Mulya ${ }^{1}$, Muhammad syandi fahrizal ${ }^{2}$ \\ Program Sudi Keselamatan dan Kesehatan Kerja, \\ Fakultas Vokasi, Universitas Balikpapan \\ widya@uniba-bpn.ac.id
}

\begin{abstract}
ABSTRAK
Code blue digunakan untuk menandakan adanya pasien yang sedang mengalami henti nafas, henti jantung di Rumah Sakit. Tim code blue melakukan Cardiopulmonary Resuscitation (CPR) yaitu tindakan pertolongan pertama pada orang yang mengalami henti napas, kemudian melakukan defibrilasi yaitu menganalisis irama jantung secara otomatis dan memberikan kejutan listrik untuk mengembalikan irama jantung dengan alat medis Automatic External Defibrillator (AED) (standar waktu tanggap petugas terhadap keadaan darurat code blue yaitu 3 - 5 menit menurut American Heart Association). Menurut data Rumah Sakit Umum Daerah Abdul Wahab Sjahranie Samarinda (Mei 2019), kejadian darurat code blue terjadi 12 kali dalam 3 tahun terakhir dengan diagnosa gagal jantung kongestif (decompensate cordis). Tujuan penelitian yaitu untuk mengetahui tanggap darurat medis (code blue) studi kasus pada Rumah Sakit Umum Daerah Abdul Wahab Sjahranie di Samarinda. Penelitian ini dilakukan dengan cara observasi langsung dan simulasi serta wawancara mendalam terkait waktu tanggap petugas terhadap kejadian darurat code blue. Berdasarkan hasil simulasi code blue pada Tanggal 04 Juli 2019, bahwa waktu tanggap petugas terhadap keadaan darurat code blue, pasien mendapatkan CPR dan AED pada waktu 4 menit 31 detik setelah alarm berbunyi. Berdasarkan hasil observasi langsung dan wawancara mendalam, sistem tanggap darurat blue code di Rumah Sakit Umum Daerah Abdul Wahab Sjahranie sudah terdiri dari sistem alarm, sarana dan prasarana pendukung tanggap darurat, pengetahuan pekerja, sistem organisasi dan sistem prosedur. Perbaikanperbaikan yang diperlukan terdiri dari standar operasional prosedur kejadian henti jantung, standar operasional prosedur penggunaan alat defibrilasi (AED) karena petugas berpotensi mengalami beberapa bahaya saat melakukan tanggap darurat seperti shock dari alat defibrilasi otomatis, kemudian dokumentasi dan pelaporan.
\end{abstract}

Kata Kunci: Code Blue, Rumah Sakit, Tanggap Darurat Medis.

\begin{abstract}
Code blue is used to indicate the existence of patients who are experiencing breathing stop, cardiac arrest at the hospital. The code blue team performed Cardiopulmonary Resuscitation (CPR), which analyzes the hearts rhythm automatically and provides electric shocks to restore the hearts rhythm with an Automatic External Defibrillator (AED) (standard response time of officers to code blue emergencies is 3 to 5 minutes according to the American Heart Association). According to data from the Abdul Wahab Sjahranie Regional Public Hospital Samarinda (May 2019), code blue emergencies have occurred 12 times in the last 3 years with failure (decompensate cordis). The research objective
\end{abstract}


is to determine the medical emergency response (code blue) case study at Abdul Wahab Sjahranie Regional Public Hospital in Samarinda. This research was conducted by direct observation and simulation as well as in-depth interviews related to the response time of officers to code blue emergencies. Based on the simulation result of code blue on July 4, 2019, that the response time of officers to code blue emergencies, patients get CPR and AED at 4 minutes 31 seconds after the alarm sounds. Based on the result of direct observation and in-depth interviews, the code blue emergency response system at Abdul Wahab Sjahranie Regional Public Hospital consisted of an alarm system, facilities and infrastructure to support the emergency response, workers knowledge, organizational system and procedure system. Necessary improvements consist of standard operational procedures for cardiac arrest events, standard operating procedures for the use of defibrillation equipment (AED) because officers have the hazard when responding to emergencies such as shock from an automatic defibrillation device, then documentation and reporting.

Keywords: Code Blue, Hospital, Medical Emergency Response.

\section{PENDAHULUAN}

Rumah sakit sebagai salah satu organisasi bergerak di bidang pelayanan kesehatan yang setiap hari berhubungan dengan pasien dan tidak lepas dari kemungkinan terjadinya sebuah keadaan darurat (emergency).

Menurut Keputusan Menteri Kesehatan Republik Indonesia Nomor 432/MENKES/SK/IV/2007, kegawatdaruratan dapat terjadi di rumah sakit. Kegawatdaruratan merupakan suatu kejadian yang dapat menimbulkan kematian atau luka serius bagi pekerja, pengunjung ataupun masyarakat atau dapat menutup kegiatan usaha, mengganggu operasi, menyebabkan kerusakan fisik lingkungan ataupun mengacam finansial dan citra rumah sakit. Rumah sakit mutlak memerlukan sistem tanggap darurat sebagai bagian dari manajemen keselamatan dan kesehatan kerja di rumah sakit.
Keadaan darurat (emergency) merupakan suatu kejadian yang tidak direncanakan atau tidak diharapkan menyerang tiba-tiba dan dapat menimbulkan kematian seperti henti jantung, stroke dan lain lain.

World Health Organization (WHO) menyatakan bahwa penyakit kardiovaskular masih merupakan penyebab kematian nomor 1 di dunia, pada tahun 2015, dilaporkan kurang lebih 17 juta orang meninggal akibat penyakit kardiovaskular, 7,4 juta diantaranya meninggal akibat penyakit jantung koroner dan 6,7 juta lainnya akibat stroke. Selain itu, dari 17 juta kasus kematian prematur, di bawah 70 tahun, akibat penyakit tidak menular, 37\% adalah akibat penyakit kardiovaskular. Penyakit kardiovaskular merupakan penyakit yang diakibatkan oleh gangguan fungsi sistem jantung dan pembuluh darah. Penyakit yang termasuk dalam penyakit kardiovaskular seperti penyakit jantung koroner, stroke, gagal 
jantung dan hipertensi

(www.kompasiana.com).

Di Indonesia, penyakit kardiovaskular juga merupakan penyebab kematian nomor 1 . Dari data World Health Organization (WHO) tahun 2014, disebutkan bahwa 37\% angka kematian di Indonesia disebabkan karena penyakit

kardiovaskular

(www.kompasiana.com).

Tanggap darurat dengan sistem emergency colour code blue yang merupakan suatu rangkaian prosedur, sistem dan protokol yang biasa digunakan pada institusi seperti rumah sakit. Code blue digunakan untuk menandakan adanya pasien yang sedang mengalami henti nafas, henti jantung di Rumah Sakit. Pada sistem ini terdapat tim yang mempunyai pelatihan khusus terhadap situasi keadaan darurat medis, sebuah tim respon cepat dengan tanggap darurat terhadap upaya penyelamatan nyawa pasien atau konsumen pada tahap yang sangat kritis. Tim code blue terdiri dari dokter dan paramedis yang ditunjuk sebagai code-team, secara cepat ke pasien untuk melakukan tindakan penyelamatan.

Tim code blue melakukan Cardiopulmonary Resuscitation (CPR) yaitu tindakan pertolongan pertama pada orang yang mengalami henti napas, kemudian melakukan defibrilasi yaitu menganalisis irama jantung secara otomatis dan memberikan kejutan listrik untuk mengembalikan irama jantung dengan alat medis Automatic External Defibrillator. Penderita henti jantung mendadak harus ditangani secara dini dan hal pertama yang paling disarankan adalah tindakan resusitasi jantung paru-paru (CPR). Menurut Adelia Masrisa didalam Annisa (2017), meski henti jantung menyebabkan terhentinya aliran darah, masih ada kesempatan untuk mengirimkan darah ke otak, meskipun hanya sebesar $15 \%$ dari total kebutuhan otak untuk berfungsi normal. Hal ini dapat dilakukan melalui resusitasi jantung paru-paru atau biasa disebut CPR. Cara ini cukup membantu untuk memperlambat kematian sel otak, namun masih tidak cukup untuk memulai otak kembali bekerja. Semakin lama CPR tertunda, kematian sel otak akan semakin cepat terjadi.

\section{Menurut American Heart Association} dalam Penelitian dan Pengembangan Yayasan Ambulans Gawat Darurat 118 (2012), menjelaskan bahwa penanganan cepat untuk cardiacrespiratory arrest atau henti jantung paru-paru adalah 3 - 5 menit setelah pasien terserang henti jantung untuk mendapatkan segera Cardiopulmonary Resuscitation (CPR) dan defibrilasi dengan alat medis Automatic External Defibrillator (AED).

Rumah Sakit Umum Daerah Abdul Wahab Sjahranie Samarinda merupakan rumah sakit besar yang memiliki perkerja sebanyak 1.635 orang (Tahun 2018). Sebagai 
rumah sakit besar, tentunya rumah sakit ini memiliki departemen Keselamatan dan Kesehatan Kerja (K3) yang telah berjalan. Pada rumah sakit ini memiliki beberapa prosedur tanggap darurat mulai dari penanganan limbah Bahan Berbahaya dan Beracun (B3), tanggap darurat kebakaran dan hingga sistem Emergency Colour Codes. Khususnya untuk Emergency Colour Codes Blue yang rampung Tahun 2017.

Menurut data rekam medik Rumah Sakit Umum Daerah Abdul Wahab Sjahranie Samarinda (Mei 2019), kejadian darurat blue code blue terjadi 12 kali dalam 3 tahun terakhir dengan diagnosa decompensasi cordis.

Berdasarkan latar belakang tersebut, maka dilakukan penelitian mengenai tanggap darurat medis (code blue) studi kasus pada Rumah Sakit Umum Daerah Abdul Wahab Sjahranie di Samarinda.

Rumusan masalah penelitian yaitu bagaimana tanggap darurat medis (code blue) studi kasus pada Rumah Sakit Umum Daerah Abdul Wahab Sjahranie di Samarinda?

Tujuan penelitian yaitu untuk mengetahui tanggap darurat medis (code blue) studi kasus pada Rumah Sakit Umum Daerah Abdul Wahab Sjahranie di Samarinda.

Batasan masalah dari penelitian ini yaitu hanya melakukan penelitian waktu tanggap petugas terhadap kejadian darurat code blue, mulai pasien henti jantung ditemukan sampai petugas datang dan melakukan Cardiopulmonary Resuscitation (CPR) kemudian petugas datang membawa Automatic External Defibrillator (AED) dan melakukan defibrilasi.

\section{METODE}

Jenis penelitian deskriptif kualitatif, ditujukan untuk mendeskripsikan dan menggambarkan fenomena-fenomena yang ada, baik bersifat alamiah maupun rekayasa manusia, lebih memperhatikan karakteristik, kualitas, keterkaitan antar kegiatan. Selain itu, penelitian deskriptif tidak memberikan perlakuan, manipulasi atau pengubahan pada variabel-variabel yang diteliti, melainkan menggambarkan suatu kondisi apa adanya, satu-satunya perlakuan yang diberikan hanya penelitian itu sendiri, dilakukan melalui observasi dan wawancara.

Tempat penelitian pada Rumah Sakit Umum Daerah Abdul Wahab Sjahranie di Samarinda. Pengambilan data primer dilaksanakan pada bulan Juni sampai dengan bulan Juli 2019. Informan pada penelitian ini terdiri dari 1 (satu) orang dari tim biru, 2 (dua) orang dari tim code blue, 1 (satu) orang dari bagian divisi K3MF (Keselamatan dan Kesehatan Kerja dan Manajemen Fasilitas) di Rumah Sakit Umum Daerah Abdul Wahab Sjahranie Samarinda. 
Teknik pengumpulan data pada penelitian ini dengan cara observasi langsung dan simulasi (simulasi dilaksanakan apabila kejadian darurat medis code blue yang sebenarnya tidak terjadi pada masa penelitian), wawancara mendalam, diuraikan sebagai berikut.

1. Observasi langsung dengan kelengkapan berupa lembar observasi, stopwatch dan alat rekam kamera. Data yang didapatkan berupa waktu tanggap petugas terhadap kejadian darurat code blue.

2. Wawancara mendalam dengan kelengkapan berupa pedoman wawancara, alat tulis dan alat perekam suara.

Pengolahan data pada penelitian ini dengan cara membandingkan hasil observasi langsung dengan waktu tanggap henti jantung menurut American Heart Association dalam Penelitian dan Pengembangan Yayasan Ambulans Gawat Darurat 118 dan hasil wawancara mendalam akan disajikan dengan penjelasan secara deskriptif.

Analisis data pada penelitian ini dengan menelaah hasil observasi langsung dan hasil wawancara mendalam mengenai faktor-faktor yang dapat mengganggu waktu tanggap petugas terhadap kejadian darurat code blue di Rumah Sakit Umum Daerah Abdul Wahab Sjahranie Samarinda. Berdasarkan hasil analisis tersebut maka dibuat rancangan Standar Operasional Prosedur (SOP) tentang code blue di Rumah Sakit Umum Daerah Abdul Wahab Sjahranie Samarinda.

\section{HASIL DAN PEMBAHASAN}

Hasil observasi langsung adalah sebagai berikut.

1. Pada masa penelitian tidak ditemukan kejadian darurat medis code blue yang sebenarnya, sehingga hasil observasi langsung berupa hasil simulasi yang dilaksanakan oleh pihak Rumah Sakit.

2. Simulasi code blue dilaksanakan pada Tanggal 04 Juli 2019, Pukul 11.00 WITA.

3. Prosedur simulasi code blue:

a. Pasien henti jantung ditemukan. Henti jantung ditandai oleh denyut nadi besar tak teraba (karotis femoralis, radialis) disertai kebiruan (sianosis) atau pucat sekali, pernapasan berhenti atau satu-satu (gasping, apnu), dilatasi pupil tak bereaksi terhadap rangsang cahaya dan pasien tidak sadar (Alkatiri didalam Annisa, 2017).

b. Seseorang menelepon Medical Emergency Call Center (MECC) 456.

c. Petugas datang dan melakukan Cardiopulmonary Resuscitation (CPR).

d. CPR atau resusitasi jantung paru-paru merupakan tindakan pertolongan pertama pada orang yang mengalami henti napas. 
e. Petugas datang membawa Automatic External Defibrillator (AED) dan melakukan defibrilasi pada boneka peraga.

f. Automatic External Defibrillator (AED) merupakan alat medis yang dapat menganalisis irama jantung secara otomatis dan memberikan kejutan listrik untuk mengembalikan jantung.

g. Simulasi berakhir.

h. Hasil observasi langsung simulasi disajikan pada tabel 1 .

Tabel 1. Hasil Observasi Langsung Simulasi Waktu Tanggap Petugas Terhadap Kejadian Darurat Code Blue

\begin{tabular}{|c|c|c|c|c|}
\hline Teori & $\begin{array}{c}\text { Keadaan } \\
\text { Langsung }\end{array}$ & $\mathrm{Ya}$ & Tidak & Keterangan \\
\hline $\begin{array}{l}\text { Saat } \\
\text { pasien } \\
\text { terseran } \\
\text { g henti } \\
\text { jantung, } \\
\text { waktu } \\
\text { tanggap } \\
\text { darurat } \\
\text { code } \\
\text { blue } \\
\text { adalah } \\
3-5 \\
\text { menit, } \\
\text { untuk } \\
\text { segera } \\
\text { mendap } \\
\text { atkan } \\
\text { CPR } \\
\text { dan } \\
\text { AED. }\end{array}$ & $\begin{array}{l}\text { Pasien } \\
\text { mendapat } \\
\text { kan CPR } \\
\text { dan AED } \\
\text { pada } \\
\text { waktu } 4 \\
\text { menit } 31 \\
\text { detik } \\
\text { setelah } \\
\text { alarm } \\
\text { berbunyi. }\end{array}$ & $\sqrt{ }$ & & $\begin{array}{l}\text { Pada saat } \\
\text { alarm } \\
\text { berbunyi, } \\
\text { tim biru } \\
\text { bergegas } \\
\text { memberika } \\
\text { n CPR } \\
\text { kepada } \\
\text { pasien dan } \\
1 \text { (satu) } \\
\text { petugas } \\
\text { dari tim } \\
\text { biru } \\
\text { mengambil } \\
\text { AED (siap } \\
\text { digunakan } \\
\text { pada waktu } \\
4 \text { menit } 17 \\
\text { detik } \\
\text { setelah } \\
\text { alarm } \\
\text { berbunyi). }\end{array}$ \\
\hline
\end{tabular}

Sumber: Hasil Observasi Peneliti
Berdasarkan hasil observasi langsung dari simulasi yang dilaksanakan oleh pihak Rumah Sakit pada tabel 1, waktu tanggap petugas terhadap keadaan darurat code blue, pasien mendapatkan CPR dan AED pada waktu 4 menit 31 detik setelah alarm berbunyi, menurut American Heart Association dalam Penelitian dan Pengembangan Yayasan Ambulans Gawat Darurat 118 (2012), menjelaskan bahwa saat pasien terserang henti jantung, waktu tanggap darurat medis code blue adalah 3 - 5 menit, untuk segera mendapatkan CPR dan AED. Disamping itu, AED siap digunakan pada waktu 4 menit 17 detik setelah alarm berbunyi, dikarenakan terdapat pembagian tugas dimana 1 (satu) petugas dari tim biru yang mengambil AED.

Code blue adalah kondisi darurat medis yang terjadi di dalam area rumah sakit. Kondisi darurat medis ini membutuhkan perhatian segera. Sebuah code blue harus segera dimulai setiap kali seseorang ditemukan dalam kondisi henti jantung atau henti nafas (tidak responsif, nadi tidak teraba atau korban tidak bernapas). Menurut American Heart Association dalam Penelitian dan Pengembangan Yayasan Ambulans Gawat Darurat 118 (2012), menjelaskan bahwa penanganan cepat untuk cardiacrespiratory arrest atau henti jantung paru-paru adalah 3-5 menit setelah pasien terserang henti jantung untuk mendapatkan segera dengan Cardiopulmonary Resusitation 
(CPR) dan defibrilasi dengan Automatic External Defibrillator (AED). Basic Life Support (BLS) dengan CPR dan AED sedangkan Advance Life Support (ALS) dengan obat-obatan. BLS merupakan suatu tindakan penanganan yang dilakukan dengan sesegera mungkin dan bertujuan untuk menghentikan proses yang menuju kematian, sedangan ALS merupakan usaha yang dilakukan setelah dilakukan usaha hidup dasar dengan memberikan obat-obatan yang dapat memperpanjang hidup pasien. Selama penangan dengan ALS cepat dilakukan, tingkat bertahan hidup terhadap dampak yang diakibatkan oleh henti jantung akan meningkat lebih dari 50\%. Untuk setiap menit yang tertunda untuk penggunaan defibrillation, 7 $10 \%$ dari survival rate pasien akan menurun. Menurut Penelitian dan Pengembangan Yayasan Ambulans Gawat Darurat 118 (2012), penatalaksanaan Advance Life Support (ALS) memiliki persentase pada tabel 2 .

Tabel 2. Persentase Keterlambatan Advance Life Support (ALS)

\begin{tabular}{l|l}
\hline \multicolumn{1}{c}{ Keterlambatan } & Kemungkinan Berhasil \\
\hline$<1$ menit & $98 \%$ \\
$1-2$ menit & $79 \%-88 \%$ \\
$2-3$ menit & $69 \%-78 \%$ \\
$3-4$ menit & $51 \%-68 \%$ \\
$4-5$ menit & $41 \%-50 \%$ \\
$5-6$ menit & $31 \%-40 \%$ \\
$6-7$ menit & $21 \%-30 \%$ \\
$7-8$ menit & $11 \%-20 \%$ \\
$8-9$ menit & $2 \%-10 \%$ \\
$9-$ lebih dari 10 menit & $1 \%$ \\
\hline
\end{tabular}

Sumber: Basic Trauma Life Support and Basic Cardiac Life Support (2012)
Menurut Purnomo (2012), tujuan dari code blue adalah:

1. Untuk memberikan resusitasi dan stabilisasi bagi korban yang mengalami kondisi darurat cardiorespiratory arrest yang berada dalam kawasan rumah sakit.

2. Untuk membentuk suatu tim yang terlatih lengkap dengan peralatan medis darurat yang dapat digunakan dengan cepat.

3. Untuk memulai pelatihan keterampilan Basic Life Support (BLS) dengan CPR dan AED.

4. Untuk memulai penempatan peralatan AED di berbagai lokasi strategis di dalam kawasan rumah sakit untuk memfasilitasi respon cepat bagi keadaan darurat medis.

5. Untuk membuat rumah sakit mampu menangani keadaan medis yang darurat.

Tim code blue merupakan tim yang dibutuhkan dan wajib selalu siap setiap saat, dikarenakan keadaan code blue tidak dapat diprediksi dan dapat terjadi kapan saja. Pembentukan struktur organisasi juga penting didalamnya, organisasi harus jelas dari pihak tertinggi hingga anggota terbawah guna mengoptimalisasi kegiatan secara organisasi lebih efisien. Tim code blue respon primer beranggotakan kru yang paling tidak telah menguasai Basic Life Support (BLS) tim code blue terdiri dari 3 sampai 4 anggota yaitu 1 koordinator tim, 1 petugas medis, 1 assisten petugas medis dan 1 atau 2 perawat (perawat 
pelaksana dan tim resusitasi), 1 kelompok pendukung (optional/jika diperlukan).

Henti jantung merupakan kegagalan fungsi kelistrikan jantung yang menyebabkan sirkulasi darah menuju otak, paru-paru dan organ lain terganggu. Kesempatan pasien untuk bisa bertahan hidup berkurang 7 sampai 10 persen pada tiap menit yang berjalan tanpa cardiopulmonary resusictation (CPR) dan defibrilasi dengan alat medis Automatic External Defibrillator (AED) (American Heart Association dalam Penelitian dan Pengembangan Yayasan Ambulans Gawat Darurat 118, 2012), penanganan secara cepat dapat diwujudkan jika terdapat tenaga medis yang memiliki kemampuan dalam melakukan CPR saat cardiac arrest terjadi, tenaga medis dan paramedis di rumah sakit sudah memiliki kemampuan dasar dalam melakukan life saving, akan tetapi belum semuanya dapat mengaplikasikannya secara maksimal.

Pada penelitian Kandou, dkk (2018), hasil penelitian mendapatkan sebanyak 27 perawat $(29,67 \%)$ mempunyai tingkat pengetahuan tentang code blue system dengan kategori tinggi, 23 perawat $(25,28 \%)$ dengan kategori cukup tinggi, 24 perawat $(26,37 \%)$ dengan kategori rendah, dan 17 perawat $(18,68 \%)$ dengan kategori sangat rendah. Dengan kesimpulan berupa mayoritas perawat di RSUP Prof. Dr. R. D. Kandou Manado mempunyai tingkat pengetahuan tentang code blue system pada kategori tinggi.

Training dan drill pada Rumah Sakit Abdul Wahab Sjahranie disajikan pada tabel 3.

Tabel 3. Hasil Wawancara Training dan Drill

\begin{tabular}{|c|c|c|}
\hline Teori & $\begin{array}{c}\text { Keadaan } \\
\text { Langsung }\end{array}$ & Keterangan \\
\hline $\begin{array}{l}\text { Sertifikat Basic } \\
\text { Life Support dan } \\
\text { Advanced Life } \\
\text { Supprot } \\
\text { diwajibkan bagi } \\
\text { anggota tim } \\
\text { code blue. }\end{array}$ & Sesuai & $\begin{array}{l}\text { Petugas yang } \\
\text { menjalankan } \\
\text { tanggap darurat } \\
\text { code blue telah } \\
\text { menjalankan } \\
\text { pelatihan BLS dan } \\
\text { ALS. }\end{array}$ \\
\hline $\begin{array}{l}\text { Drill/ pelatihan } \\
\text { secara internal } \\
\text { minimal } 1 \text { tahun } \\
\text { sekali. }\end{array}$ & Sesuai & $\begin{array}{l}\text { Sudah dilakukan } \\
\text { pada Tanggal } 5 \text { Juli } \\
2019 \text {. }\end{array}$ \\
\hline
\end{tabular}

Sumber: Hasil Wawancara Mendalam Peneliti

Berdasarkan hasil wawancara mendalam pada tabel 3, sertifikat Basic Life Support/Bantuan Hidup Dasar dan sertifikat Advanced Life Support telah dilaksanakan pada Rumah Sakit Abdul Wahab Sjahranie.

Sistem organisasi code blue pada Rumah Sakit Abdul Wahab Sjahranie adalah tim code blue yang mengkoordinir tim-tim biru disetiap zona, terdiri dari 5 zona, disetiap tim-tim biru sendiri dikepalai oleh seorang ketua tim dengan cara kerja bila terjadi kejadian code blue, ketua tim ini akan segera bergegas dengan anggota timnya ke lokasi kejadian dizonanya, tim code blue juga akan segera menyusul untuk memberikan pertolongan. Ini telah sesuai dengan pembagian tim pada 
pengorganisasian dari Code Blue Rapid

Response System For Resuscitation (2012).

Pendistribusian AED kit telah sesuai dengan sarana dan prasarana pada Code Blue Rapid Response System For Resuscitation (2012). Pendistribusian AED kit di Rumah Sakit Abdul Wahab Sjahranie meliputi:

1. 1 AED kit di depan ruang flamboyant.

2. 1 AED kit di depan ruang kemoterapi.

3. 1 AED kit di depan ruang radiologi.

4. 1 AED kit pada kantor utama.

Standar operasional prosedur Rumah Sakit Abdul Wahab Sjahranie disajikan pada tabel 4.

Tabel 4. Hasil Wawancara Mendalam Mengenai Standar Prosedur

\begin{tabular}{|c|c|c|}
\hline Teori & $\begin{array}{c}\text { Keadaan } \\
\text { Langsung }\end{array}$ & Keterangan \\
\hline $\begin{array}{l}\text { Memiliki } \\
\text { standar } \\
\text { operasional } \\
\text { prosedur } \\
\text { kejadian henti } \\
\text { jantung. }\end{array}$ & Tidak sesuai & $\begin{array}{l}\text { Masih belum } \\
\text { adanya standar } \\
\text { prosedur yang } \\
\text { mengatur } \\
\text { tentang apabila } \\
\text { ada kejadian } \\
\text { henti jantung } \\
\text { paru-paru. }\end{array}$ \\
\hline $\begin{array}{l}\text { Memiliki } \\
\text { standar } \\
\text { operasional } \\
\text { prosedur } \\
\text { melakukan } \\
\text { resusitasi } \\
\text { jantung paru- } \\
\text { paru (CPR). }\end{array}$ & Sesuai & $\begin{array}{l}\text { No. Dokumen } \\
\text { 089/Bidkep/VIII } \\
\text { /2015 }\end{array}$ \\
\hline $\begin{array}{l}\text { Memiliki } \\
\text { standar } \\
\text { operasional } \\
\text { prosedur } \\
\text { penggunaan } \\
\text { alat defibrilasi } \\
\text { (AED). }\end{array}$ & Tidak sesuai & $\begin{array}{l}\text { Ada, namun } \\
\text { masih belum } \\
\text { tersahkan, masih } \\
\text { adanya } \\
\text { perbaikan dalam } \\
\text { perencanaan dan } \\
\text { pembuatannya }\end{array}$ \\
\hline
\end{tabular}

Berdasarkan hasil wawancara mendalam pada tabel 4, sistem code blue rumah sakit wajib memiliki minimal 3 standar operasional prosedur yaitu standar operasional prosedur kejadian henti jantung, standar operasional prosedur melakukan resusitasi jantung paruparu $(\mathrm{CPR})$ dan standar operasional prosedur penggunaan alat defibrilasi (AED) (Purnomo, 2012). Dari 3 standar operasional prosedur tersebut, Rumah Sakit Abdul Wahab Sjahranie memiliki prosedur Tatalaksana Resusitasi Jantung Paru-paru dengan No. Dokumen 089/Bidkep/VIII/2015. Maka pada penelitian ini melakukan perancangan standar operasional prosedur kejadian henti jantung berdasarkan Code Blue Rapid Response System For Resuscitation (2012), diharapkan dapat membantu dalam membangun sistem prosedur pada tanggap darurat medis code blue.

Tahapan-tahapan prosedur pertama, menemukan korban atau pasien henti jantung, segera menekan tombol emergency atau berteriak meminta pertolongan jika memungkinkan. Petugas jaga datang memastikan korban sadar atau tidak sadar dengan cara menepuk dan memanggil korban dengan suara lantang (catat waktu kejadian untuk informasi operator call center, tim biru maupun code blue Rumah Sakit Abdul Wahab Sjahranie). 
Kedua, petugas jaga melakukan panggilan pada nomor call center Rumah Sakit Abdul Wahab Sjahranie yaitu 456, mengaktifkan announcement call center Rumah Sakit Abdul Wahab Sjahranie sebanyak 3 kali tentang kejadian darurat code blue, petugas jaga melakukan CPR pada pasien sampai tim biru dan tim code blue datang mengambil alih. Dari hasil wawancara, sistem speaker yang digunakan untuk announcement sering rusak ataupun tidak berfungsi dengan baik dibeberapa lokasi.

Ketiga, tim biru yang mendengar dan mengetahui terjadi keadaan darurat code blue dizonanya, segera menuju lokasi kejadian dengan 1 (satu) anggota dari tim mengambil dan membawa alat defibrilasi (AED) ke lokasi kejadian. Tim segera mengambil alih penanganan terhadap pasien dan tetap melakukan CPR. Setelah AED siap digunakan, petugas akan segera melakukan tindakan defibrilasi kepada pasien henti jantung. Biarkan alat melakukan analisis terhadap pasien, ikuti petunjuk yang tertera pada alat defibrilasi (AED), jangan bersentuhan dengan pasien apabila AED memerintahkan perintah shock, karena pada saat alat melakukan shock, alat akan memberikan kejutan berupa aliran listrik pada pasien.

Keempat, pada saat tim code blue sampai dilokasi kejadian segera mengambil alih pasien, namun tim biru yang sebelumnya telah menangani pasien tetap sebagai tim bantuan. tim code blue melanjutkan $\mathrm{CPR}$, defibrilasi menggunakan AED dan pemberian obat berkala hingga pasien sadar atau dinyatakan meninggal.

Kelima, jika pasien berhasil disadarkan, akan dipindahkan ke IGD untuk mendapatan resusitasi dan perawatan lebih lanjut. Jika resusitasi tidak berhasil atau pasien meninggal, akan dipindahkan ke IGD/ICCU untuk dilakukan konfirmasi kematian dan dokumentasi lebih lanjut. Diharapkan semua kejadian tanggap darurat medis code blue didokumentasikan dan dibuat pelaporannya guna evaluasi dan kebutuhan medik lainnya.

\section{SIMPULAN}

Berdasarkan hasil penelitian dan pembahasan, peneliti menyimpulkan bahwa waktu tanggap petugas terhadap keadaan darurat code blue, pasien mendapatkan $\mathrm{CPR}$ dan AED pada waktu 4 menit 31 detik setelah alarm berbunyi, menurut American Heart Association dalam Penelitian dan Pengembangan Yayasan Ambulans Gawat Darurat 118 (2012), menjelaskan bahwa saat pasien terserang henti jantung, waktu tanggap darurat medis code blue adalah 3 - 5 menit, untuk segera mendapatkan CPR dan AED.

Sistem tanggap darurat blue code di Rumah Sakit Umum Daerah Abdul Wahab Sjahranie sudah terdiri dari sistem alarm, 
sarana dan prasarana pendukung tanggap darurat, pengetahuan pekerja, sistem organisasi dan sistem prosedur. Perbaikanperbaikan yang diperlukan terdiri dari standar operasional prosedur kejadian henti jantung, standar operasional prosedur penggunaan alat defibrilasi (AED) karena petugas berpotensi mengalami beberapa bahaya saat melakukan tanggap darurat seperti shock dari alat defibrilasi otomatis, kemudian dokumentasi dan pelaporan.

\section{DAFTAR PUSTAKA}

American Heart Association, 2015, Guidelines 2015 CPR \& ECC, Circulation, dilihat 30 September 2019, $<$ http://circ.ahajournals.org $>$.

Arrifudin, Annisa Mutmainnah, 2017, Cardiorespiratory Arrest, Universitas Muslim Indonesia Makassar, Makassar.

Kandou, P. R. D., Dame, R. B., \& Kumaat, L. T., 2018, 'Gambaran Tingkat Pengetahuan Perawat Tentang Code Blue System' Jurnal E-Clinic (ECL), vol. 6 , no. 2 , hh. 162-168.

Kompasiana, 2017, Henti Jantung, dilihat 30 September 2019 , <http://www.kompasiana.com>.

Keputusan Menteri Kesehatan Republik Indonesia Nomor 432/MENKES/SK/IV/2007， 2007, Pedoman Manajemen Kesehatan dan Keselamatan Kerja (K3), Menteri Kesehatan Republik Indonesia, Jakarta.
Purnomo, Perdana R., dkk, 2012, Code Blue Rapid Response System For Resuscitation, Universitas Brawijaya, Malang.

Rumah Sakit Umum Daerah Abdul Wahab Sjahranie Samarinda, 2015, Tatalaksana Resusitasi Jantung Paru-paru, Dokumen 089/Bidkep/VIII/2015, Samarinda. 